\title{
TOPIRAMATE FOR THE TREATMENT OF JUVENILE MYOCLONIC EPILEPSY
}

\author{
Patrícia da Silva Sousa, Gerardo Maria de Araújo Filho, \\ Eliana Garzon, Américo C. Sakamoto, Elza Márcia T. Yacubian
}

\begin{abstract}
Objective: The aim of this study was to evaluate the efficacy and tolerability of topiramate (TPM) in juvenile myoclonic epilepsy (JME). Method: We assessed seizure control and adverse effects of TPM in 22 patients (18 females) aged 13 to 53 years. Ta rget TPM dosage was up to $200 \mathrm{mg} /$ day. The patients were subdivided into 3 groups: those treated with seizure control plus side effects $(n=4)$; treated with non-controlled seizures $(n=15)$ and with JME newly diagnosed $(n=3)$. Results: Sixteen patients completed the first year of the follow-up. Generalized tonic-clonic seizures were completely controlled in $10(62.5 \%)$; more than $50 \%$ of reduction in $4(25.0 \%)$ and less than $50 \%$ in $2(12.5 \%)$. Myoclonia were controlled in $11(68.8 \%)$ and persisted in $5(31.2 \%)$ patients. Absence seizures were present in $5(22.7 \%)$ of whom $2(9.0 \%)$ showed more than $50 \%$ of seizure reduction while $3(13.6 \%)$ presented worsening. Discontinuations were due to inadequate seizure control and adverse events $(\mathrm{N}=4)$, low compliance and loss of follow-up $(\mathrm{N}=2)$ and subject choice $(\mathrm{N}=1)$. Conclusion: TPM showed to be an effective and well-tolerated drug in the treatment of JME. Although frequently observed, TPM side effects were tolerable and the drug could be maintained in the majority of patients.
\end{abstract}

KEY WORDS: topiramate, treatment, juvenile myoclonic epilepsy.

\begin{abstract}
Tratamento da epilepsia mioclônica juvenil com topiramato
RESUMO - Objetivo: Avaliar a eficácia e tolerabilidade do topiramato (TPM) na epilepsia mioclônica juvenil (EMJ). Método: Avaliamos a resposta terapêutica e efeitos colaterais do TPM em 22 pacientes (18 mulheres) com idades entre 13 e 53 anos. A dose alvo utilizada foi até $200 \mathrm{mg} / \mathrm{dia}$. Os pacientes foram divididos em 3 grupos no início do tratamento: aqueles com controle das crises mas que apresentavam efeitos colaterais $(n=4)$; com crises não controladas $(n=15)$ e com EMJ recém diagnosticada $(n=3)$. Resultados: Dezesseis pacientes completaram o primeiro ano de acompanhamento. Crises tônico-clonicas generalizadas foram completamente controladas em 10 (62,5\%), tiveram redução maior de $50 \%$ em 4 (25,0\%) e menor de $50 \%$ em $2(12,5 \%)$. Mioclonias foram controladas em $11(68,8 \%)$ e persistiram em $5(31.2 \%)$ pacientes. As crises de ausências, presentes em $5(22,7 \%)$ pacientes, tiveram redução maior do que $50 \%$ em $2(9,0 \%)$ e agravamento em $3(13,6 \%)$. A retirada do estudo foi devida principalmente ao controle inadequado das crises e efeitos colaterais indesejáveis $(n=4)$, pouca adesão e perda do seguimento $(n=2)$ e escolha do paciente $(n=1)$. Conclusão: TPM foi considerada droga eficaz e bem tolerada no tratamento da EMJ. Apesar de freqüentemente observados, os efeitos colaterais do TPM foram toleráveis e a medicação pode ser mantida na maioria dos pacientes.
\end{abstract}

PALAVRAS-CHAVE: topiramato, tratamento, epilepsia mioclônica juvenil.

Va I p roate (VPA) has been considered the drug of choice in the treatment of juvenile myoclonic epilepsy (JME). Different series ${ }^{1-3}$ reported good to excellent control of seizures in $70-85 \%$ of patients with VPA monotherapy or polytherapy. VPA is effective in the three types of seizures, generalized tonic-clonic seizures (GTCS), myoclonia and absences, which characterize this syndrome. Despite its satisfactory efficacy, side effects such as weight gain, polycistic ovary and hormonal disturbance have led to other therapeutical strategies.

Recently, topiramate (TPM), lamotrigine and zonisamide have also been shown to be effective in this syndrome ${ }^{4-7}$. TPM may represent a therapeutic alternative in JME since it has an equally broad profile. In fact, some studies have demonstrated the efficacy of TPM in generalized seizures, including those of $\mathrm{JME}^{8}$. Others have suggested that des-

Unidade de Pesquisa e Tratamento das Epilepsias, Escola Paulista de Medicina/Universidade Federal de São Paulo (UNIFESP), São Paulo, SP Brazil. This research was supported by FAPESP (Fundação de Amparo a Pesquisa do Estado de São Paulo) and CAPES (Coordenação de Aperfeiçoamento de Pessoal de Nível Superior).

Received 10 March 2005, received in final form 13 May 2005. Accepted 20 June 2005.

Dra. Elza Márcia Targas Yacubian - Rua Cruz e Souza 53/11 - 01532-040 São Paulo SP - Brasil. E-mail: yacubian@zaz.com.br 
pite the effectiveness of TPM in the control of GTCS, its efficacy in the control of absences and myoclonic seizures is poorer ${ }^{4,6}$.

This is a prospective study for evaluation of efficacy and tolerability of TPM in a series of patients with JME.

\section{METHOD}

In this study we included 22 JME patients followed up between March 15t, 2003, and January 1 $1^{\text {st }}, 2005$ at Hospital São Paulo Epilepsy Outpatient Clinic, Universidade Federal de São Paulo. The Ethic Committee of the institution approved the protocol, and informed consent was obtained from all participants.

TPM was administered as a first drug or as a substituted drug in the treatment of the 22 patients (13-53 yr.; mean 23.2). Eight patients were being treated with VPA (500-2000 mg/day, in 2 of them associated with clonazepam 3 and $10 \mathrm{mg} /$ day), 4 with CBZ (600-1400 mg/day), 2 PB $(100 \mathrm{mg} /$ day $)$, one with oxcarbazepine $(600 \mathrm{mg} /$ day), one with lamotrigine $(25 \mathrm{mg} /$ day). Six patients were not being treated. These patients were divided into three groups. Groups 1 and 2 included patients already being treated with other AED and were constituted by: (a) patients with controlled seizures but presenting side effects $(n=4)$; (b) patients already receiving AED but with noncontrolled seizures ( $n=15)$ and (c) patients with newly diagnosed JME $(n=3)$. TPM was titrated according to patients' response over 12-14 weeks and maintained for an additional 32 weeks. Target TPM dosage was reached with the increase of $25 \mathrm{mg}$ each 15 days up to $200 \mathrm{mg} /$ day.
The doses of the initial therapy were reduced $25 \%$ of initial doses per week. The exit criteria were occurrence of GTCS or intolerable side effects. The patients were evaluated in the $2^{\text {td }}, 4^{\text {th }}, 6^{\text {th }}, 8^{\text {th }}$ and $12^{\text {th }}$ weeks and then in the $6^{\text {th }}, 9^{\text {th }}$ and $12^{\text {th }}$ months as to therapeutic effect and adverse events. Patients and family quantified the number of GTCS, myoclonia and absences per day in a diary. Psychiatric evaluation was performed in all patients and body mass index (BMI) was registered in each visit.

Statistical analysis - The small number of participants did not allow statistical comparison of TPM efficacy in $p$ reviously treated and untreated groups. The comparison of those who presented seizure control, those with seizu res not controlled and discontinued groups after TPM introduction was assessed by individual seizure type response and registered by frequency (\%). TPM tolerability data was evaluated. Schedule Clinical Interview for $D S M-I V$ (SCID I) was performed to measure depression and humor instability. BMI at the beginning and at the end of follow-up was compared using paired t-test of Student. We considered statistically significant $p<0.05$.

\section{RESULTS}

Efficacy - Twenty-two patients (18 females) were enrolled, 16 of whom completed the first year of the follow-up (Figure). The mean dosage among study completers varied from $50 \mathrm{mg}$ to $175 \mathrm{mg}$ per day (mean $106.25 \pm 55.43 \mathrm{mg} /$ day). Suppression or reduction $>50 \%$ of the frequency of seizures occurred in 15 patients (68.2\%). Sixteen patients com-

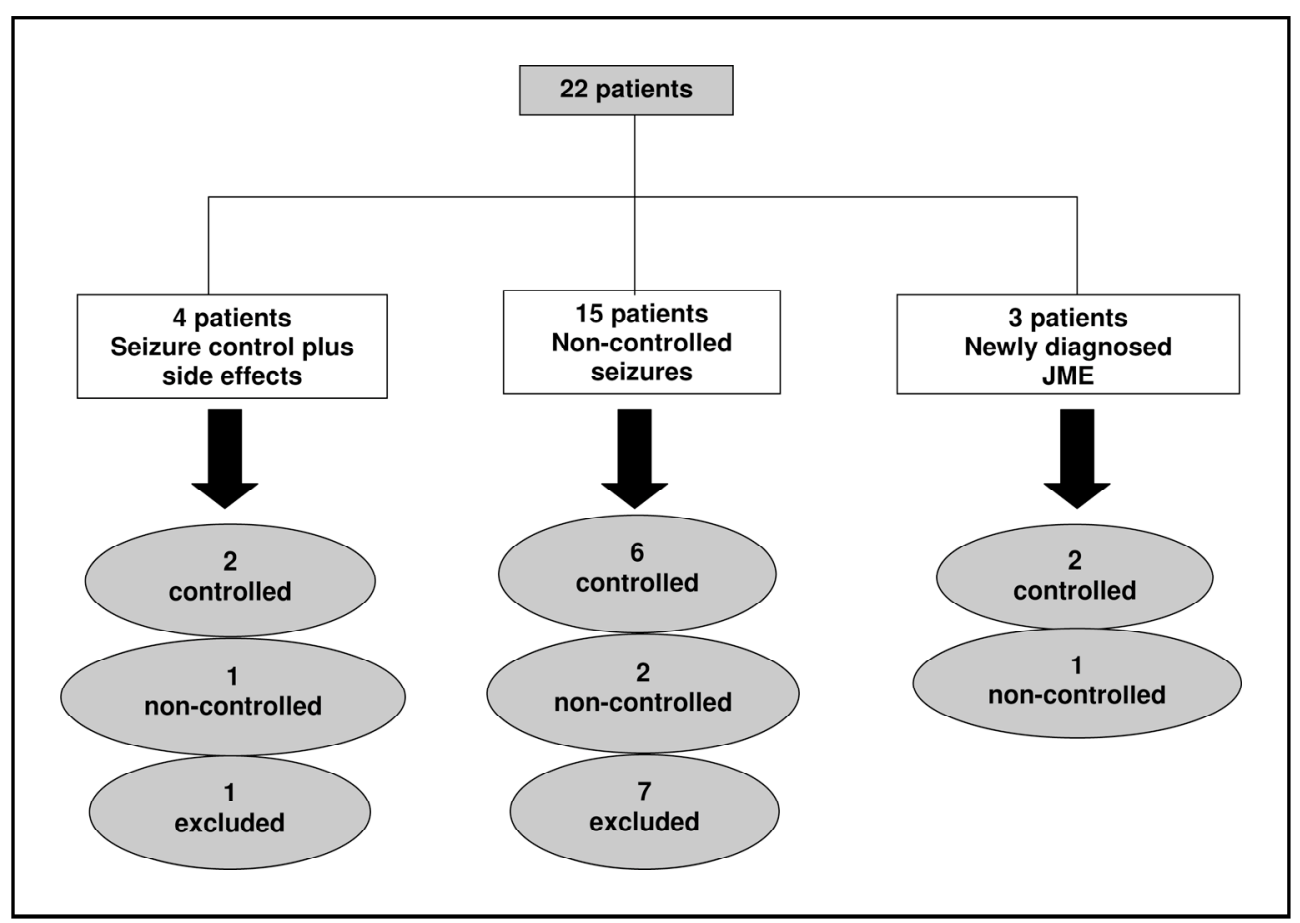

Figure. Fluxogram of patien's follow-up. 


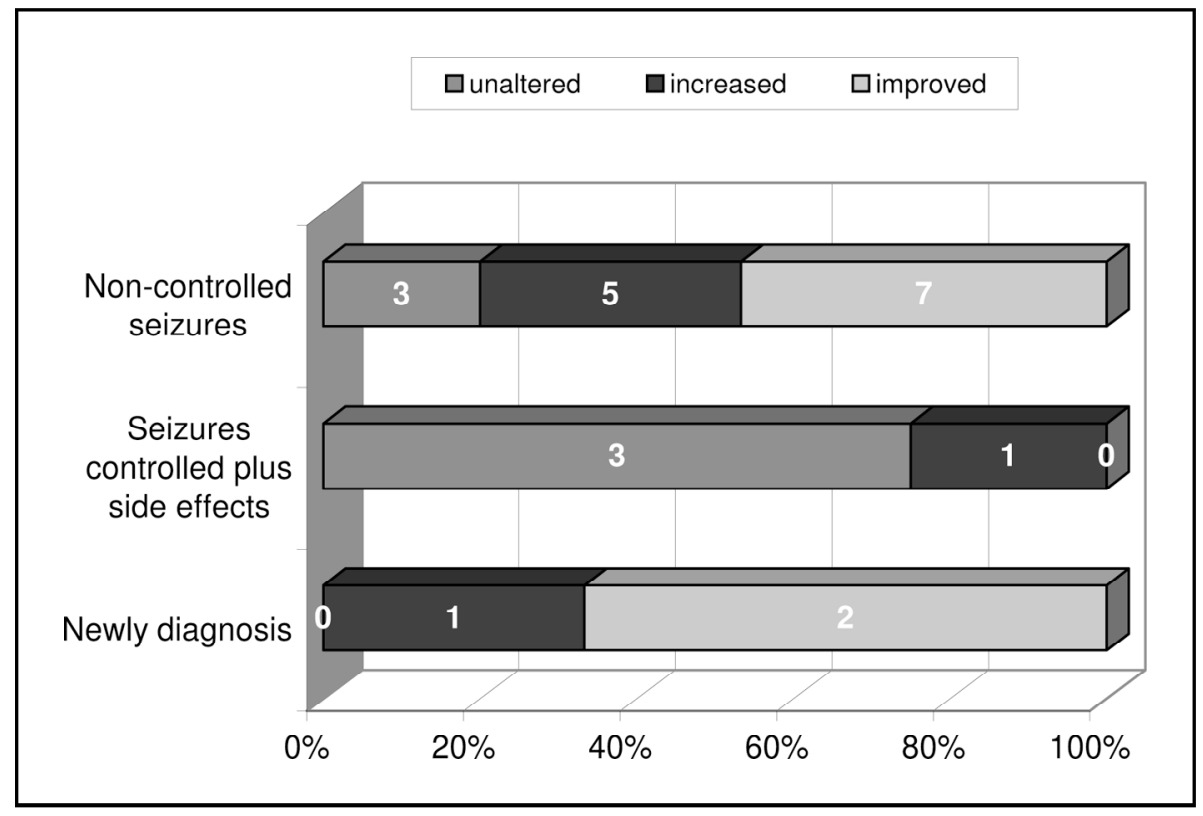

Graphic 1. Evolution of myoclonia after topiramate according to group studied.

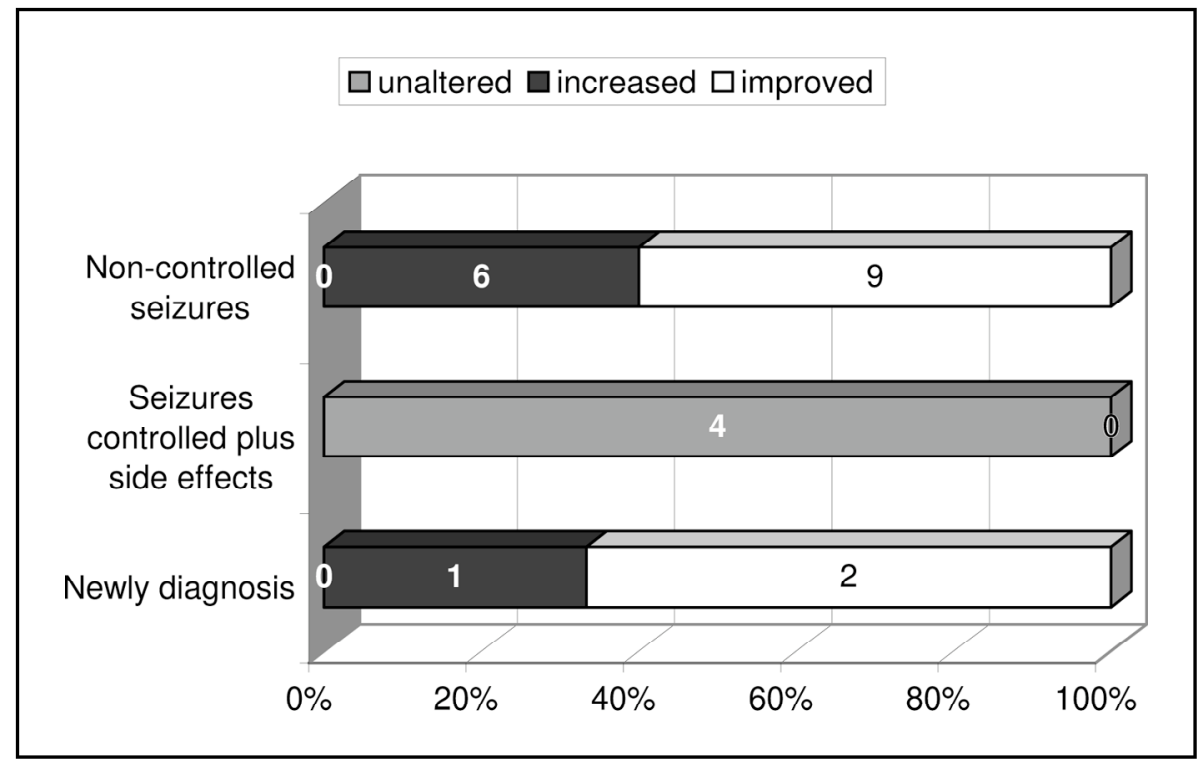

Graphic 2. Evolution of generalized tonic-clonic seizures after TPM according to group studied .

pleted the first year of the follow-up. In relation to GTCS, present in 16 patients, there was complete seizure control in $10(62.5 \%)$, more than $50 \%$ of GTCS reduction in $4(25.0 \%)$ while $2(12.5 \%)$ presented less than $50 \%$. Myoclonia also present in 16 patients, were controlled in $11(68.8 \%)$ and persisted in $5(31.2 \%)$ patients. Absence seizures were present in $5(27.7 \%)$ patients of whom $2(9.0 \%)$ showed more than $50 \%$ of seizure reduction while 3 $(13.6 \%)$ presented worsening of this seizure type. The frequency of myoclonia and GTCS is showed in Graphics 1 and 2. Most of the patients with con- trolled seizures plus side effects and those newly diagnosed had their seizures controlled. Among those who persisted having seizures despite the use of other AED before TPM introduction, myoclonia were improved in $46.6 \%$, maintained the same frequency in $20 \%$ and showed aggravation in $33.3 \%$, while GTCS were improved in $60 \%$ and aggravated in $40 \%$.

Tolerability - The most prevalent side effect was weight loss. At the enrollment, $11(50 \%)$ of the patients were over-weight $\left(\mathrm{BMI}>25 \mathrm{~kg} / \mathrm{m}^{2}\right)$ while 


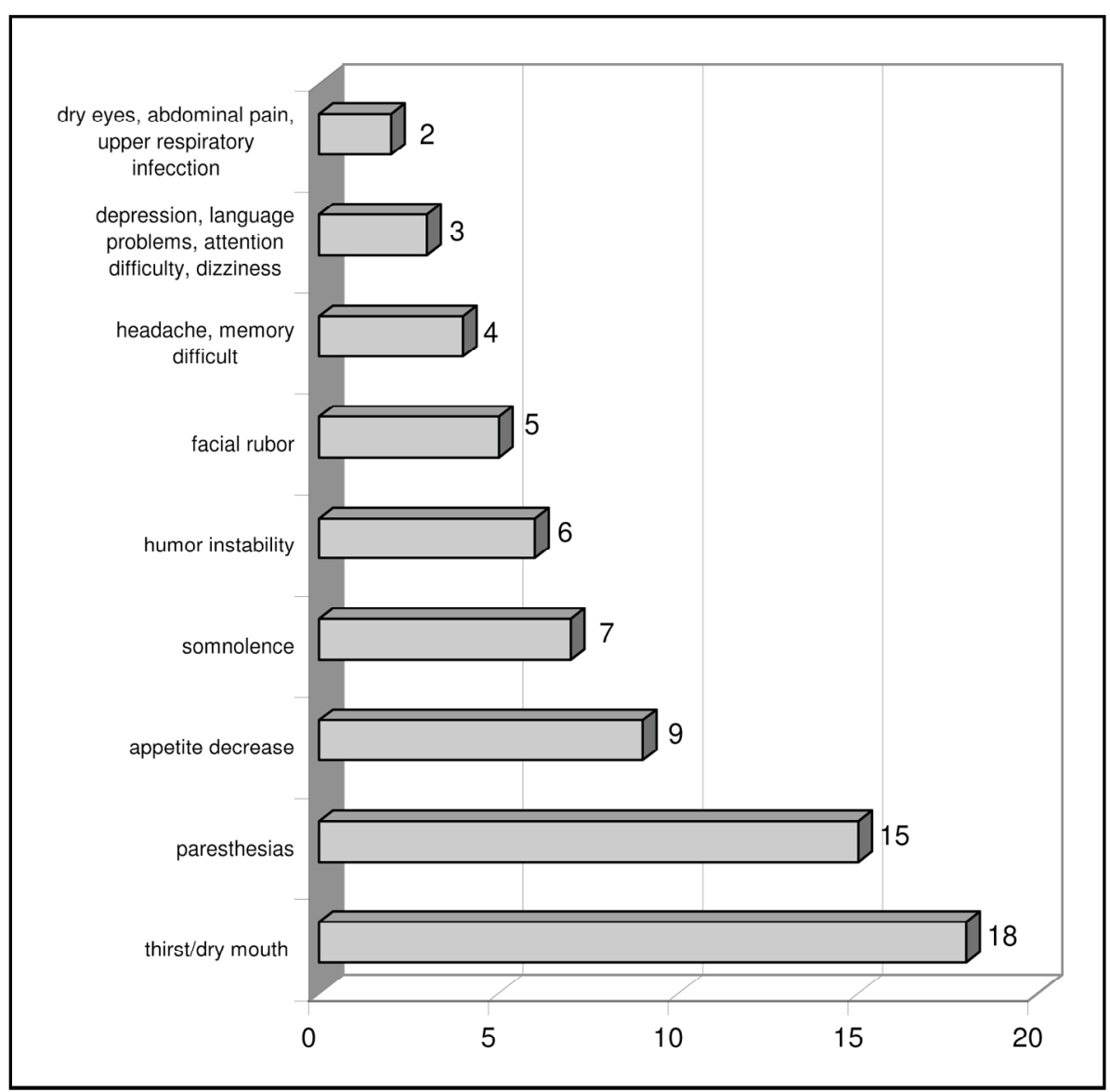

Graphic 3. Most common adverse events during all treatment.

$7(31.8 \%)$ were obese (BMI > $30 \mathrm{~kg} / \mathrm{m} 2)$. All overweight patients lost weight, $4(36.4 \%)$ lost $>10 \%$ of weight, 6 (54.5\%) lost 5-10\% while 1 (9.1\%) lost $<5 \%$. Among those obese, $4(57 \%)$ lost $>10 \%$. At the moment of this evaluation, the mean absolute variation of weight from the beginning to the end of the follow up was $-5.49 \pm 1.35 \mathrm{~kg}(\mathrm{p}=0.001$ paired T test) and the mean variation of BMI was $2.13 \pm 0.51$ ( $p=0.001$ paired $t$ test).

The other side effects (Graphic 3 ) were re p resented by thirst/dry mouth $(81.8 \%)$, paresthesias $(68.2 \%)$, appetite decrease $(40.9 \%)$, somnolence $(31.8 \%)$, humor instability $(27.3 \%)$, facial rubor $(22.8 \%)$, headache/memory difficulty $(18.2 \%)$, depression/language problems/attention difficulty/dizziness (13.7\%), dry eyes/ abdominal pain/ upper respiratoryinfection $(9.0 \%)$. Paresthesias and dry mouth were more common during the titration phase and tended to vanish after three months of therapy. These side effects were tolerable and the drug could be maintained in the majority of patients. Depression, language problems and attention difficulty were observed in 3 patients who were on TPM > $100 \mathrm{mg}$. Humor instability was registe- red in 6 patients who were on TPM 50-75 mg. These symptoms persisted with maintenance of the dosages; three of these patients had some benefit of fluoxetine $20 \mathrm{mg} /$ day.

Discontinuations were either due to inadequate seizure control and adverse events $(\mathrm{N}=4)$ or low compliance and loss of follow-up ( $\mathrm{N}=2)$ and subject choice $(\mathrm{N}=1)$.

\section{DISCUSSION}

TPM has proven to be effective in treatment of generalized epilepsy9. In patients with JME, it was initially shown that TPM was effective in cases refractory to other AED ${ }^{10}$, and later its efficacy was demonstrated in patients with recent onset epilepsy and intolerable side effects of other AED ${ }^{4,5,8}$.

In a previous study, Rosenfeld et al. ${ }^{4}$ evaluated the efficacy of TPM in 15 adults with JME. Fourteen of these patients had not achieved seizure control with VPA and/or presented excessive weight gain after institution of VPA therapy (5 subjects). TPM in an average dose of $663 \mathrm{mg} /$ day improved seizure frequency in 11 patients, maintained control in two 
and led to worsening in two. In the series of Prasad et al. ${ }^{5}$, TPM used in a minimum effective dose of $230 \mathrm{mg}$ in monotherapy and $250 \mathrm{mg}$ in polytherapy was considered to be an alternative to VPA. Tolerability to TPM was lower than to VPA, which the authors attributed to excessively rapid titration of the drug; in this series, one of the $19 \mathrm{pa}$ tients showed worsening of the seizures. Levisohn et al. ${ }^{6}$ compared the efficacy of TPM vs. VPA in recently diagnosed JME patients. Twelve of 19 patients randomized to TPM concluded the study, and so did 7 out of the 9 patients in the VPA group. The average dose of TPM in the patients who concluded the study was $250 \mathrm{mg} /$ day, in comparison to $750 \mathrm{mg} /$ day of VPA.

In our series, TPM was administered in a lower dose (50 to $175 \mathrm{mg}$ per day) than that of previous studies. This is a tendency in the most recent series p resented that have shown minimization of side effects with maintained efficacy with low dose. In a series of drug naive older patients with recently diagnosed partial-onset seizures Ramsay et al. ${ }^{11}$ showed that $50 \mathrm{mg}$ of TPM as monotherapy, was similar to $200 \mathrm{mg}$. In the study of Edwards et al. ${ }^{12}$ TPM $100 \mathrm{mg} /$ day was shown to be at least as effective as $600 \mathrm{mg} /$ day of carbamazepine and 1250 $\mathrm{mg} /$ day of VPA in newly diagnosed generalized and focal epilepsies. These results agreed with previous observations such as that of Kwan and Bro$\mathrm{die}^{13}$ who mentioned the necessity of low-to-moderate dosages of AED in patients successfully treated with monotherapy.

In our series, TPM reduced the seizure frequency in approximately $2 / 3$ of patients with JME in the first year of follow-up, seeming more effective in the control of GTCS and myoclonia than in absence seizures, despite the small number of patients with this last seizure type. However, this study shows that TPM may aggravate GTCS and myoclonia al- though this was observed only in the group of patients with more refractoryseizures. Side effects we re frequently observed in all patients. Some of them, such as thirst and paresthesias, tended to $\mathrm{di}$ minish with time, while other dose-dependent effects such as emotional instability, depression and language difficulties were persistent in patients with dosage over $100 \mathrm{mg} /$ day.

Although frequently observed, TPM side effects we re tolerable and the drug could be maintained in the majority of the patients.

Acknowledgement - We thank Mrs. Miriam Adams for English editing and Mrs Roberta Trefiglio for statistical assistance.

\section{REFERENCES}

1. Covanis A, Gupta AK, Jeavons PM. Sodium valproate: monotherapy and polytherapy. Epilepsia. 1982;23:693-720.

2. Delgado-Escueta AV, Enrile-Bacsal F. Juvenile myoclonic epilepsy of Janz. Neurology 1984;34:285-294.

3. Penry JK, Dean JC, Riela AR. Juvenile myoclonic epilepsy. Epilepsia 1989;30(Supp14):S19-S23.

4. Rosenfeld WE. Topiramate, a broad-spect rumagent, in patients with juvenile myoclonic epilepsy. Epilepsia 1999;40(Suppl 2):226.

5. Prasad A, Kuzniecky R, Knowlton RC, et al. Evolving antiepileptic drug treatment in juvenile myoclonic epilepsy. A rch Neurol 2003;60: 1110-1103.

6. Levisohn PM, Holland KD, Hulihan JF, Fisher AC. Topiramate versus valproate in patients with juvenile myoclonic epilepsy. Epilepsia 2003; 44(Suppl 9):S267-S268.

7. Kothare SV, Valencia I, Khurana DS, Hardison H, Melvin DO, Legido A. Efficacy and tolerability of zonisamide in juvenile myoclonic epilepsy. Epileptic Disord 2004;6:267-270.

8. Biton V, Montouris GD, Ritter F, et al. A randomized, placebo-controlled study of topiramate in primary generalized tonic-clonic seizures. Neurology 1999;52:1330-1337.

9. Barrera MN. Characteristics and indications of topiramate. Rev Neurol 2002;35:88-95.

10. Kellett MW, Smith DF, Stockton PPA, Chad wick DW. Topiramate in clinical practice: first year's postlicensing experience in a specialist epilepsy clinic. J Neurol Neurosurg Psychiatry 1999;66:759-763.

11. Ramsay RE, Rowan AJ, Spitz M, et al. A double-blind study of topiramate (TPM) monotherapy in older patients with partial-onset seizures. Epilepsia 2004;45(Suppl 7):S127.

12. Edwards JC, Privitera MD, Neto W, Wu SC. Topiramate vs. carbamazepine and valproate in newly diagnosed epilepsy: effectiveness according to seizure type. Epilepsia 2004;45(Suppl 7):S139.

13. Kwan P, Brodie MJ. Effectiveness of first antiepileptic drug. Epilepsia. 2001;42:1255-1260. 